\title{
The Efficacy of Teacher-Parent Rapport on B osnian High School Students' English Language Skills
}

Ekrem Eroz, PhD.c

\author{
Azamat A. Akbarov, PhD
}

International Burch University

\section{Doi:10.5901/mjss.2014.v5n4p656}

\section{Abstract}

\begin{abstract}
In education, the efficacy of teacher-parent rapport (interconnection) is of great importance in learner's educational, social and private life. I think parents can play a pivotal role in fostering a very delicate and crucial relationship between the student and the teacher. Accordingly, family is a positive ignition in learner's learning process at any given time. In this study, we set our sights on to research the efficacy of teacher-parent rapport on 32 Bosnian high school EFL learners' competency in their target language. Add to that, we researched to decide the function of Bosnian learners' families' roles in education and to detect whether this rapport prompts the parents or not. In this study, we held a correspondence with parents by' Smart School' (eschool). It is called 'elektroniski dnevnik' in Bosnia. Smart School applications are primarily developed for the purpose of better informing parents, having in mind to be short, light and offer more accessible way to obtain information about the marks and the absence of their child. By way of addition, in our research, parents had ability to check grades online through the internet and we sent SMS messages. By these Smart School mails and messages, we daily informed parents about learner's marks in exams and quizzes, projects, and the learner's behavioral matters and absence or presence of their children. At the end of this study, we have found that daily interconnection and corresponding with parents can improve the learner's English markedly. Especially home-visit of English teacher to student's home was appreciated by parents. In parallel with, the high value that we have given to this rapport honored parents and prompted them.
\end{abstract}

Keywords: EFL learners, teacher-parent rapport, English language, prompt, Smart school

\section{Introduction}

In education, there is an inseparable triangle system and the parts of this triangle are teacher, student and parent. The triangular responsibility for student development should be shared by the teacher, student and parents equally. We should foster effective school triangles. Although all the three are involved in this triangle, unfortunately the graceless task of shouldering the great burden lies with the teacher solely. The teacher will not mind teaching, as long as the other two partners (learner and parent) contribute their shares in moderate measures. The expectation of teacher here would be more from the parents than from the learner himself, for the clear reason that the parent has a steady contact and that is why, an expansive control over his child. So he is naturally more concerned about how best to bring to parents properly into the circle of responsibility without appearing to be too demanding on their time. Thus, as we mentioned before, parents can play a pivotal role in fostering a crucial rapport between the student and teacher, and any slip by them, may cause a disaster that could be very steep for the learner.

Constant parent involvement seriously increases the expectancy that suitable learning will occur in the classroom and at home. Parents play such a crucial role in their children's academic, physical, social, and moral development that we, as teachers, make a huge mistake if we view them as anything other than indispensable collaborators. If we are committed to bringing the best out of our students and teaching the whole child, we need to build long-term relationships of loyalty, trust, and reverence with their parents. Investing the time and effort to work closely with parents throughout the year, increases our chances of following our mission and meeting our goals.

Parents are often valuable classroom resources. The better we know parents, the more we will be aware of the various ways in which they can assist the class. This assistance may come in such forms as classroom volunteering, donations of supplies and other materials, technology support, and arranging for special field trips. Forming trusting relationships with parents can reduce the feelings of isolation that so many teachers, especially newer ones, often experience. (Reifman, 2011)

A skilled teacher is experienced in imparting knowledge and managing the classroom in a way that generally 
works for her and her students. Yet, regardless of how creative some teachers are at handling large classes and a variety of needs, often there isn't the ideal time and circumstance to tend to each child. This is where a parent's role becomes important. Parents are experts about their own children. They are likely to be the first to notice changes in their children that might either affect, or derive from, the school environment. By coordinating with teachers whether about academic or personal issues parents can help smooth the way for their children and maximize the effectiveness of teachers' time.

In order to find an adequate place in the society the students need both the support of their parents and the school. This goal can be achieved when all who participating in the education process of the pupil cooperate. This cooperation provides help; create opportunities for a genuine partnership among parents, teachers and students. It will help to enable the youth to leave the school and enter the community without a shock.

A child performs better if $s / h e$ feels his/her parents are supportive of her school. If $s / h e$ perceives that both parents and teachers are in agreement about issues related to school, this united front gives a child clear guidance. If a child feels dissention between parents and teachers, there is too much likelihood that s/he will respond with manipulation or other negative behaviors. However, when teacher, student and parent work together toward a common goal, there is no room to deviate from the subject into controversial roles. Energy, instead, can be devoted to positive accomplishments. The teacher is most aware of how parents can be helpful academically to the children in her class. Teacher is expert on how he is teaching the curriculum, when she wants a child to work independently and when a little help from a parent is appropriate. A parent who listens to the teacher's suggestions about how to assist the child will be the most useful to the child.

If the student perceives that her teachers and parents have a good rapport, s/he will not be caught in the anxiety of feeling that she can't please either. If the parent has a different idea that might help her child, s/he can communicate this to the teacher directly, and they can come to a mutually agreed position. In this way, rapport is maintained in the child's eyes (Holman, 2012).

There is significant research to suggest that parental involvement in children's learning is positively related to achievement. Cotton and Wikelund (1989) in their study on parental involvement in education propose that the more intensely parents are involved in their children's learning; the more beneficial are the effects on pupil achievement. Moreover, they state that this holds true for all types of parental involvement in children's learning and for all types and ages of pupils.

\section{Purpose of the Research}

In Bosnia, the population of young generation is too low so it is easy for every high school graduate to study in university. That is why, parents generally visit the school once a term or never where their child studies unless there is a big problem in school like fighting, failing in the exams etc.. They think that teacher is the only person who shapes his child on his own. As I teacher, my ideal parent is who always in touch with teacher of his child and follow his/ her studies with care during the year.

Teachers and parents need to have a continual good rapport during the term to improve the learner's language development. The purpose of this research is to determine how teacher- parent rapport affects the Bosnian high school learners' English language proficiency. In our research, we have 2 English classes with 16 students in each. We will use one of them as an empirical class and the other as a control class. These two groups will have two English KET exams. The first exam will be taken at the beginning of the research and they will take a final exam ( 15 weeks later) at the end of the term. Then we will try to determine whether the scores of students in empirical class differ from first exam to final exam. At the same time, we will try to determine whether the scores of students in control class differ from first exam to last exam.

As it was mentioned before, this research study was an attempt to investigate the efficacy of teacher-parent rapport on Bosnian high school students' success in English. We used KET ( Key English Test) exam. KET is a basic level qualification English language test.

\subsection{Contributors}

This research study was carried out with the participation of 32 male elementary-level English language high school students at Sarajevo College in Bosnia and Herzegovina. The proficiency level of the students was determined by a KET test done in Sarajevo. The 32 contributors (participants) were between 15 to 16 years old. They were grouped as 
empirical and control groups. I was the English teacher of both the empirical group and control group and still I am. They had English six hours in a week. I used almost the same techniques, methods and materials in these two different classes.

\subsection{Instruments}

In the beginning of the school in September, both of these classes had, KET (Key English Test), a proven proficiency test to have idea about the students English language ability and homogeneity of their English skills. KET was my first instrument to achieve my goal. KET was adopted from British Council. (British Council, 2013, KET).

My second instrument was Smart School system where I mailed and sent messages, daily and weekly, to my students' parents about their marks, absences, their participation in activities, homework, behavioral problems, their birthdays etc. Also by using this system, they sent me so many mails. My third instrument was 'Aim High 2'workbook, student's and teacher's books, Oxford University Press.(Tim Falla \& Paul Davies, 2013). The last instrument was final KET exam which tried to evaluate the course achievement. KET was implemented to both empirical and control classes. Thenceforth, the two scores of (first KET \& second KET) were compared. As a result of the first KET, students were divided into two sixteen students groups as empirical and control groups. I, as researcher and the English teacher of the classroom, put the students of each group into equal KET level proficiency. That means both empirical and control groups were at the same English level. Both of these groups had 15 weeks of intensive English courses in the school.

The parents of the empirical group students routinely involved in education and they were in contact with me (English teacher), being pivotal role in their child's English learning and moral science teacher of their child. Parents were like live camera which was monitoring 24 hours in 15 weeks. After first KET exam was implemented, the parents of empirical group were called to school and informed about their active and energetic pivotal role in this research. Then they received daily and weekly mails, messages and reports by Smart school system about anything concerning their child. Moreover, every parent called individually by English teacher every Saturday and once home - visit was done by English teacher to student's home. After 15 weeks inspired with full hope,

The English teacher implemented the last KET to empirical and control groups to bring to light whether there existed any visible difference between the students in the two groups.

\section{Results}

Here are the final KET results of the control and empirical group students.

- How much do students improve after 15 weeks study?

In the table 1; We will see the language improvements of students in control group.

In the table 2: We will see the improvement of students in empirical group in which teacher- parent had good rapport (relation) on the students' language learning.

The only difference between the two modes of estimation was that:

In empirical group there was the efficacy of teacher-parent rapport factor on the Bosnian learner's language learning process.

In the table 1 below: we will see the improvement of students in control group after 15 weeks intensive study.

Table 1. Control group students' final KET results.

Control Group KET December 2013 Results (Sarajevo College)

\begin{tabular}{|c|c|c|l|c|c|c|c|}
\hline Rank & School & Class & Surname Name & Reading and Writing & Listening & $\%$ & Cambridge ESOL Standard Result \\
\hline 1 & $\mathrm{SCl}$ & $1 \mathrm{~A}$ & Selim Kenan & 53 & 21 & 87.06 & PASS WITH MERIT \\
\hline 2 & $\mathrm{SCl}$ & $1 \mathrm{~A}$ & Krespo Zlatkom & 50 & 24 & 87.06 & PASS WITH MERIT \\
\hline 3 & $\mathrm{SCl}$ & $1 \mathrm{~A}$ & Radžiahmetović Sakir & 49 & 24 & 85.88 & PASS WITH MERIT \\
\hline 4 & $\mathrm{SCl}$ & $1 \mathrm{~A}$ & Hamzić Amel & 50 & 22 & 84.71 & PASS \\
\hline 5 & $\mathrm{SCl}$ & $1 \mathrm{~A}$ & Keč Omer & 50 & 22 & 84.71 & PASS \\
\hline 6 & $\mathrm{SCl}$ & $1 \mathrm{~A}$ & Idrizović Amir & 44 & 23 & 78.82 & PASS \\
\hline 7 & $\mathrm{SCl}$ & $1 \mathrm{~A}$ & Hajić Semir & 46 & 20 & 77.65 & PASS \\
\hline 8 & $\mathrm{SCl}$ & $1 \mathrm{~A}$ & Hasanbegović Latif & 45 & 21 & 77.65 & PASS \\
\hline 9 & $\mathrm{SCl}$ & $1 \mathrm{~A}$ & Alibegović Saris & 41 & 23 & 75.29 & PASS \\
\hline
\end{tabular}




\begin{tabular}{|c|c|c|l|c|c|c|c|}
\hline 10 & $\mathrm{SCl}$ & $1 \mathrm{~A}$ & Agović Sedim & 46 & 18 & 75.29 & PASS \\
\hline 11 & $\mathrm{SCl}$ & $1 \mathrm{~A}$ & Manjgafić Kemal & 42 & 22 & 75.29 & PASS \\
\hline 12 & $\mathrm{SCl}$ & $1 \mathrm{~A}$ & Merdžanić Nermin & 41 & 23 & 75.29 & PASS \\
\hline 13 & $\mathrm{SCl}$ & $1 \mathrm{~A}$ & Pupalović Adise & 43 & 20 & 74.12 & PASS \\
\hline 14 & $\mathrm{SCl}$ & $1 \mathrm{~A}$ & Zaimović Ali & 39 & 22 & 71.76 & PASS \\
\hline 15 & $\mathrm{SCl}$ & $1 \mathrm{~A}$ & Teco Abu & 41 & 17 & 68.24 & LEVEL A2 \\
\hline 16 & $\mathrm{SCl}$ & $1 \mathrm{~A}$ & Ajdin Tarik & 38 & 19 & 67.06 & LEVEL A2 \\
\hline
\end{tabular}

In the table 2 below: we will see 'How did the teacher-parent rapport contribute to Bosnian students' improvement on KET?

Table 2. Emprical group students' final KET results. ( teacher-parent rapport)

Emprical Group KET December 2013 Results (Sarajevo College)

\begin{tabular}{|c|c|c|l|l|c|c|c|}
\hline Rank & School & Class & Surname Name & Reading and Writing 60 & Listening 25 & $\%$ & Cambridge ESOL Standard Result \\
\hline 1 & $\mathrm{SCl}$ & 1B & lbrahimović Selim & 60 & 24 & 98.82 & PASS WITH DISTINCTION \\
\hline 2 & $\mathrm{SCl}$ & 1B & Lutura Esat & 58 & 25 & 97.65 & PASS WITH DISTINCTION \\
\hline 3 & $\mathrm{SCl}$ & 1B & Slovo Vedit & 58 & 25 & 97.65 & PASS WITH DISTINCTION \\
\hline 4 & $\mathrm{SCl}$ & 1B & Jusuf Faris & 58 & 24 & 96.47 & PASS WITH DISTINCTION \\
\hline 5 & $\mathrm{SCl}$ & 1B & Tiril Emir & 57 & 25 & 96.47 & PASS WITH DISTINCTION \\
\hline 6 & $\mathrm{SCl}$ & 1B & Sećirspahis Tamza & 57 & 24 & 95.29 & PASS WITH DISTINCTION \\
\hline 7 & $\mathrm{SCl}$ & 1B & Mrka Fuat & 56 & 25 & 95.29 & PASS WITH DISTINCTION \\
\hline 8 & $\mathrm{SCl}$ & 1B & Račanović Harik & 56 & 25 & 95.29 & PASS WITH DISTINCTION \\
\hline 9 & $\mathrm{SCl}$ & 1B & Hinić Murat & 56 & 25 & 95.29 & PASS WITH DISTINCTION \\
\hline 10 & $\mathrm{SCl}$ & 1BB & Nulahalilovic Palik & 56 & 25 & 95.29 & PASS WITH DISTINCTION \\
\hline 11 & $\mathrm{SCl}$ & 1B & Salkanović Hamit & 57 & 23 & 94.12 & PASS WITH DISTINCTION \\
\hline 12 & $\mathrm{SCl}$ & 1B & Sašić Edin & 55 & 25 & 94.12 & PASS WITH DISTINCTION \\
\hline 13 & $\mathrm{SCl}$ & 1B & Coso Denis & 55 & 25 & 94.12 & PASS WITH DISTINCTION \\
\hline 14 & $\mathrm{SCl}$ & 1B & Fišić Selim & 55 & 25 & 94.12 & PASS WITH DISTINCTION \\
\hline 15 & $\mathrm{SCl}$ & 1B & RAvdičević Kerim & 56 & 23 & 92.94 & PASS WITH DISTINCTION \\
\hline 16 & $\mathrm{SCl}$ & 1B & Brabus Varis & 55 & 24 & 92.94 & PASS WITH DISTINCTION \\
\hline
\end{tabular}

Independent - sample t-test was used to compare the results of the first KET in order to find out whether there were any significant differences between the control group and empirical group in September. To analyze the results of the final KET, we used t-test.

This study was a research to see the efficacy of teacher-parent rapport on Bosnian high school students English language skills. At the beginning, the proficiency level of the students was determined by a KET (Key English Test) exam. 16 students were assigned to the control group and a class of 16 students were chosen as empirical group.

At the end of the 15 weeks, 32 students' final KET exam scores in both groups were compared to determine the 'efficacy of teacher-parent rapport on Bosnian students' language proficiency'.

In the following sections the results of each test will be put under the investigation one by one to find out if there were any important differences between the results of the control group and the empirical group' tests or not.

\subsection{First Question: Do the scores of students in empirical group significantly differ from first KET to the final KET?}

Table 3 shows the results of paired sample t-test through which empirical group scores in first and final KET tests were compared. By considering the mean of the first KET which is 15.34 and the mean of the final KET which is 21.55 we can conclude that there is a huge improvement in the scores of the empirical group. Table 4 shows that scores of students in the empirical group significantly differs from the first KET at the beginning of the term to the final KET after 15 weeks. This reveals that teacher-parent rapport has improved Bosnian students' language skills. 
Table 3: Comparison of first KET and final KET (empirical group)

\begin{tabular}{|c|c|c|c|c|}
\hline & Mean & $\mathrm{N}$ & Std. Deviation & Std. Error Mean \\
\hline sum of scores first KET & 15.3400 & 25 & .65542 & .13908 \\
sum of scores final KET & 21.5500 & 25 & .71970 & .14994 \\
\hline
\end{tabular}

Table 4: paired Samples Statistics t-test for the empirical group

\begin{tabular}{|c|c|c|c|c|c|c|c|c|}
\hline \multirow{3}{*}{ KET } & \multicolumn{5}{|c|}{ Paired Differences } & \multirow{3}{*}{ t } & \multirow{3}{*}{ df } & \multirow{3}{*}{ Sig. (2- tailed) } \\
\hline & \multirow[t]{2}{*}{ Mean } & \multirow[t]{2}{*}{ Std. Deviation } & \multirow{2}{*}{$\begin{array}{l}\text { Std. Error } \\
\text { Mean }\end{array}$} & \multicolumn{2}{|c|}{$\begin{array}{l}\text { 90\% Confidence Interval of the } \\
\text { Difference }\end{array}$} & & & \\
\hline & & & & Lower & Upper & & & \\
\hline First and final KET & 5.18000 & .80134 & 27026 & -5.75103 & -5.22799 & -13.817 & 24 & .0001 \\
\hline
\end{tabular}

According to the above T-Test table, Sig equals 0.0002 and it is smaller than 0.04 . So we can conclude that students' scores on the final KET in the empirical group are significantly different from their scores on the first test. According to the results students in empirical group have got better and higher scores in final KET than on the first KET.

\subsection{Second Question: Do the scores of students in control group significantly differ from first KET to the final KET?}

Table 5 shows the results of paired sample t-test through which the control group scores in the first and final KET were compared. The mean of 13.2500 for the first KET and 13.7700 for the final KET reveals the fact that the difference between the scores on the first KET and final KET was indifferent and insignificant and there were no improvements. Table 5 shows that the scores of students in the control group do not significantly differ from the first KET at the beginning of the term to the final KET at the end of the term.

Table 5: Comparison of first and final KET (control group)

\begin{tabular}{|c|c|c|c|c|}
\hline KET & Mean & $\mathrm{N}$ & Std. Deviation & Std. Error Mean \\
\hline sum of scores first KET & 13.2500 & 25 & .63232 & .13554 \\
sum of scores final KET & 13.7700 & 25 & 1.03266 & .10724 \\
\hline
\end{tabular}

According to the below T-Test Table, Sig equals 0.52 and it is greater than 0.04 .So we can conclude that students' scores in the final KET in the control group are not significantly different from their scores in the first KET. Table 4 and Table 5 indicate that students in the control group have got higher scores on the second test but it is not a significant difference.

Table 6: Paired Samples Statistics t-test for the control group

\begin{tabular}{|c|c|c|c|c|c|c|c|c|}
\hline \multirow{3}{*}{ KET } & \multicolumn{5}{|c|}{ Paired Differences } & \multirow{3}{*}{$\mathrm{t}$} & \multirow{3}{*}{ Df } & \multirow{3}{*}{$\begin{array}{c}\text { Sig. } \\
\text { (2- tailed }\end{array}$} \\
\hline & \multirow{2}{*}{ Mean } & \multirow{2}{*}{ Std. Deviation } & \multirow{2}{*}{$\begin{array}{l}\text { Std. Error } \\
\text { Mean }\end{array}$} & \multicolumn{2}{|c|}{ 95\% Confidence Interval of the Difference } & & & \\
\hline & & & & Lower & Upper & & & \\
\hline first and final KET & .42000 & .60588 & .13135 & -.71127 & -.33751 & -2.572 & 36 & .512 \\
\hline
\end{tabular}

\section{Conclusion}

In my opinion, parents are the most valuable classroom resources. As we mentioned before, parents play a pivotal role in fostering a very delicate and crucial relationship between the student and teacher. Teacher-parents good rapport results in. By the end of the research parents increased their contact with their children's school and the number of parents actively involved in their children's school increased significantly.

In education, the efficacy of teacher-parent rapport (interconnection) is of great importance in learner's educational, social and private life. It is obvious that family is a positive ignition in learner's learning process. The more 
families support their children's learning and educational progress, the more the children tend to do well in school and continue their education. Students behave sensibly when they know that their parents and teachers communicate frequently.

Sometimes I, as an English, couldn't solve some discipline problems and recorded these problematic

Students' videos in the classroom and invited them to school in my office hours. Parents watched the videos and warned their children. By cooperating with my students' parents, we solved a bleeding problem which was exploded in my classroom management.

This research indicates that teacher-parent's good rapport decreases student's behavioral problems in the classroom. After the study most parents were likely to have special program to check and control their children's education. Parents represented that they were interested to spend more time with their children after school time to talk about what happened in the classroom. In this study parents enjoyed using Smart school system effectively like communication such as phone calls, e-mail messages, and face to face meetings.

\subsection{Limitations of the study}

There are some limitations in this study.

In running this research, the researcher confronted with some limitations. First of all, some of the students' parents were separated and we had difficulty in connection and confused to contact whether with father or mother. Second, negotiation with parents was not an easy endeavor because all of the parents were not very cooperative. Third students did not like their parents be informed daily or weekly from their learning process.

\section{References}

Grinberg, J. G. A. (2002). "I had never been exposed to teaching like that": Progressive teacher education at Bank Street during 1930s. Teachers College Record, 104 (7), 1422-1460.

Holmes, E. (2003) The newly qualified teacher's handbook. London and New York, Routledge Falmer.

Howard, L. F. (2006) Ready for Anything: Supporting new teachers for success. Englewood, CO, ALP: Advanced Learning Press.

Jarvis, S., \& Algozzine, B. (2006) Everything I need to know about teaching: They forgot to tell me! California, Corwin Press: Thousands Oaks.

Kellough, R. D. (2005). Your first teaching: Guidelines for success (3rd Ed.) New Jersey, Columbus, Ohio, Upper Saddl

Athanases, S. Z., \& Achinstein, B. (2003). Focusing new teachers on individual and low performing students: The centrality of formative assessment in the mentor's repertoire of practice. Teachers College Record, 105 (8), 1486-1520.

Britt, P.M. (1997). Perceptions of beginning teachers: Novice teachers reflect upon their beginning experiences. Paper presented at the Annual Meeting of the Mid-South Educational Research Association, Memphis, TN.

Gould, P. (1999, May 3). Parents are stepping out of their passive roles. San Diego Business Journal, 20(18), 6A-10A.Retrieved July 19, 2000.

Hickman,C. W., Greenwood, G., \& Miller, M. D. (1995, Spring). High school parent involvement: Relationships with achievement, grade level, SES, and gender. Journal of Research and Development in Education, 28(3), 125-132.

Howe, F., \& Simmons B.J. (2005). Nurturing the Parent-Teacher Alliance. Phi Delta Kappa Fastbacks, 531,-37.Retrieved on September 25, 2005, from ProQuest. 